\title{
Culinary Rhubarb Production in North America: History and Recent Statistics
}

\author{
Clifford M. Foust \\ Department of History, University of Maryland, College Park, MD 20742 \\ Dale E. Marshall
U.S. Department of Agriculture, Agricultural Research Service, Fruit \& Vegetable Harvesting Research Unit, Agricultural Engineering Department, Michigan State University, East Lansing, MI 48824-1323

Rhubarb's history as a highly popular laxative drug and a general tonic traces back to ancient China and the Mediterranean region, although not until the 18th Century do we come upon occasional reports of its petioles being used for food, mainly in England and English colonies. [Earlier, in England and reportedly in the Middle East, rhubarb was used as a table green like spinach or beet greens, it not being understood that the leaves can be toxic and even fatal, probably because of calcium oxalates and/or anthrone glycosides (The Lancet, 1917; Tallqvist and Vaananen, 1960).] Nonetheless, widespread table use did not occur in either North America or northern Europe until the 19th Century.

Botanists and horticulturists did not agree on the taxonomy of this crop (Akeroyd, 1989; Marshall, 1988). The finest medicinal roots and rhizomes had been carried to Europe from the hinterlands of China fairly continuously from ancient times. In the 17th and 18th Centuries, seeds of several species were brought to Europe from Asia. However, they did not breed true when propagated by seed, and many hybridized readily when planted within pollination distance, producing what was then known as bastard or mule varieties. The consequence of this hybridization was that there were soon many cultivars, leaving us uncertain as to the species origin of the culinary type. Even today, it is common to label culinary rhubarbs as Rheum rhabarbar-urn (which is the same as R. undulatum), as Bailey does (Liberty Hyde Bailey Hortorium, 1976), or as $R$. rhaponticum; but the important fact is that all of the 60 cultivars of culinary rhubarb now grown are hybrids of one sort or another. It is probably more useful to employ the botanical name $R$. x cultorum (Akeroyd, 1989).

\section{REASONS FOR INCREASED POPULARITY}

Culinary rhubarb cultivation first enjoyed great popularity in Great Britain in the first half of the 19th Century. The aggressive

\footnotetext{
Received for publication 29 Oct. 1990. The cost of publishing this paper was defrayed in part by the payment of page charges. Under postal regulations, this paper therefore must be hereby marked advertisement solely to indicate this fact.
}

marketing of vegetables and fruits, especially in the London metropolitan district, developed concurrently with the serendipidous discovery of techniques of rhubarb forcing. The result was the production of attractive, edible stalks in January or even earlier, which were marketed when few fresh vegetables or fruits were available.

Joseph Myatt, a nurseryman of south London, reputedly in 1808 or 1809 , first introduced rhubarb stalks to the Covent Garden market. Initially they failed to sell, but he stubbornly continued to market them until he found or created a demand. In the next 25 years or so, he and other growers selected cultivars, derived principally from $R$. undulatum or the older $R$. rhaponticum, which represented improved hybrids with one or more desirable characteristics: color, size, taste, firmness, etc.

The forcing of rhubarb roots was inadvertently discovered in 1815 , when earth thrown up by the digging of a ditch in Chelsea Physic Garden accidentally covered dormant rhubarb crowns. Within a few weeks, succulent rhubarb shoots with eye-catching petioles but strangely retarded leaves pushed through the moist, warm mulch in midwinter, long before field rhubarb was due to appear. (Forcing and blanching techniques for other vegetables, such as seakale, endive, and asparagus had been employed since the 17th Century.)

\section{DEVELOPMENTS LEADING TO BRITISH RHUBARB MANIA}

In the second quarter of the 19th Century, the merging of these two factors produced a great demand for rhubarb in many British circles. This dessert vegetable, associated in most minds then with the physicky taste of the cathartic medicine, broke through the taste barrier to become a culinary fashion. The rising British market stimulated experimentation in various directions. New cultivars emerged for field and forced cultivation, some of which, like Myatt's 'Victoria', continue to be used today. Forcing technology also drew much attention, from the use of darkened, heated houses to simply inverting castoff kitchenware over the rhubarb crowns. Further, production spread northward from the London region about 1820 , especially to the West Riding of Yorkshire, which soon rivaled the London region as principal producer of table rhubarb. As for table uses, the simple tart was soon too plain; rhubarb recipes multiplied by midcentury. These included rhubarb wines, which some consumers (although by no means all) found "undistinguishable from Champagne" and as a still wine "of the character of the Rhine wines, especially when it is mature" (Livett, 1850).

Finally, two technological developments contributed to the acceptance and marketing of rhubarb. Sugar production in the Caribbean rose considerably in the first half of the 19th Century, making that popular sweetener readily available in price and quantities, at least to the upper classes, and by the second half of the century to nearly all consumers as well (Mintz, 1985). For most palates, rhubarb required sugar. Second, the development of effective canning and bottling techniques allowed a variety of foodstuffs, normally available only in the growing season, to be enjoyed throughout the year, quickly enabling a wide sector of the European population to enjoy a far greater diversity in diet (Thome, 1986). Rhubarb shared in this expansion, although, in spite of the improvement of preservation techniques, fresh rhubarb continued to attract consumers in the dreary winter days.

\section{RHUBARB MANIA COMES TO NORTH AMERICA}

As with so many cultural, technological, and social movements of 18th- and 19thCentury Britain, culinary rhubarb crossed the Atlantic to America but took many decades to achieve the notoriety it had in Britain. Perhaps introduced to New England at the end of the 18th Century, extensive cultivation did not occur until the late 1840s or 1850 s. Rhubarb's popularity rose considerably, however, in the second half of the 19th Century in eastern and midwestern United States and Canada.

The culminating episode of this growth was the importation of a long-bearing cultivar from New Zealand by hybridist Luther Burbank in the early 1890s. Employing his painstaking skills of selection, Burbank developed a cultivar he named 'Australian Crimson Winter Rhubarb'. This 'Crimson' 
was exceptional in several ways; it was fieldgrown with an extraordinary season of 8 months or more (two to four harvests), far longer than any other cultivars then known, yet remained bright red and retained thick stalks with firm pulp and pleasant flavor. Developed originally at his Santa Rosa ranch north of San Francisco, it was soon carried to southern California and further hybridized, where it has augmented that state's substantial contribution to American rhubarb.

\section{PRODUCTION AND CONSUMPTION PEAKS}

By the 1920s and 1930s, rhubarb production and consumption peaked in North America (and probably in Britain and elsewhere as well). The freezing industry had not yet developed sufficiently to provide consumers with an appealing diversity of fruits and vegetables that approximated the fresh produce in appearance, flavor, and nutritional value. The costs of labor and (for hothouse or forced rhubarb) of fuels were still comparatively low. Rail transport by then linked all major population centers, and the trucking industry was expanding by the end of the 1930s, allowing the delivery of fresh rhubarb over considerable distances.

The West Coast was supplied by southern California ranchers using 'Cherry Giant' and Oregon and Washington farmers, who used cultivars such as 'Crimson' and 'German Wine', producing field and hothouse rhubarb. Eastern cities were mainly supplied by forced and field rhubarb grown in Michigan, Ohio, Illinois, Indiana, Wisconsin, and in Ontario, Canada. The center of forced rhubarb production in the United States was then Macomb County, Mich., just north of Detroit, where the small city, Utica, called itself "The Rhubarb Capital of the World."

\section{FEATURES MARKING 20th CENTURY PRODUCTION}

In spite of the ease with which the plant grows in a very wide range of climatic and soil conditions, by the 1930s commercial cultivation of rhubarb came to be heavily restricted to the few localities previously mentioned. The reasons for this phenomenon are varied. With both hothouse and irrigated cultivation, the investment was and is considerable, discouraging market production without proved access to substantial and profitable markets. The requirement of good rootstocks for successful commercial cultivation encourages rhubarb growers to zealously guard their roots, making it difficult for competitive newcomers to get started. Further, lengthy life for fecund rootstock requires that young stock not be harvested for several years, which demands a patience newcomers often did not display. Some of the horticultural techniques and practices entail esoteric knowledge and skills, particularly in hothouse cultivation. Finally, the rhubarb market has always been a small, specialty one, difficult for new growers to enter.
Furthermore, the rhubarb industry has been typified by the organization of marketing cooperatives, an element of industry stability. In the mid-1930s, cooperatives were organized in the Kent-Puyallup valley of Washington, northern California, Ontario, and Michigan. By the 1970s, Oregon growers in the Willamette valley also banded together. These associations effectively aided in the development of markets, the maintenance of uniform quality, and the safekeeping of the lore of rhubarb cultivation.

Stability of the industry over many decades is seen also in the persistence of a few grower families over several generations. Perhaps the longest-lived family was one by

the name of French, which first grew rhubarb in the 1880 s about $50 \mathrm{~km}$ west of Toronto, and has continued to farm in Ontario through four generations. In southern California, the family of Cleugh was a major producer or processor and involved three generations from their beginnings in Covina about 1925. The Ota family in Washington state and others elsewhere also testify to the unusual durability of some farm families in this specialized industry. Although the ethnic background of growers throughout the United States and Canada has been diverse, in some areas a single homogeneous group has dominated, such as Flemish farmers in Michigan and Ontario.

Table 1. U.S. rhubarb production and marketing, 1909-89.

\begin{tabular}{|c|c|c|c|c|c|}
\hline Year & $\begin{array}{l}\text { Farms } \\
(\text { no. })^{z}\end{array}$ & $\begin{array}{l}\text { Area } \\
(\text { ha })^{2}\end{array}$ & $\begin{array}{c}\text { Value } \\
(\$ 1000)^{z}\end{array}$ & $\begin{array}{c}\text { Unloads } \\
(\mathrm{t})^{y}\end{array}$ & $\begin{array}{c}\text { Frozen pack } \\
(\mathrm{t})^{\mathrm{x}}\end{array}$ \\
\hline 1909 & 1000 & 1000 & 339 & $---w$ & $\ldots$ \\
\hline 1919 & 2300 & 1000 & 673 & -.. & -.- \\
\hline 1929 & 2100 & 1600 & 853 & $-\cdot$ & $\ldots$ \\
\hline 1939 & 2900 & 2100 & 775 & $\cdots$ & --. \\
\hline 1942 & - & -. & --. &.- & 400 \\
\hline 1943 & $\cdots$ & -.. & -. & -- & 1600 \\
\hline 1944 & -. & - & $\cdots$ & $\cdots$ & 2000 \\
\hline 1945 & $\cdots$ & $-\cdots$ & $\cdots$ & $\cdots$ & 3100 \\
\hline 1946 & $\ldots$ & - & -- & $\ldots$ & 4800 \\
\hline 1947 & -. & $\cdots$ & -- & $\cdots$ & 700 \\
\hline 1948 & $\ldots$ & $-\cdots$ & -. & $\ldots$ & 1200 \\
\hline 1949 & 1800 & 1400 & $\ldots$ & - & 1900 \\
\hline 1950 & -- & -.- & -- & -- & 2800 \\
\hline 1951 & -- & --. & - & -- & 2600 \\
\hline 1952 & -.. & $-\cdots$ & - & --- & 2600 \\
\hline 1953 & -.- & --. &.- & - & 3800 \\
\hline 1954 & 1400 & 1400 & -- & -- & 3100 \\
\hline 1955 & $\cdots$ & -.- & $\cdots$ & $\cdots$ & 2500 \\
\hline 1956 & -- & $\cdots$ & $-\cdot$ & -.. & 3400 \\
\hline 1957 & -- & -- & $\cdots$ & -. & 2100 \\
\hline 1958 & $\cdots$ & $\cdots$ & -.. & -.. & 2000 \\
\hline 1959 & 1200 & 1200 & -.. & -.. & 2100 \\
\hline 1960 & $\cdots$ & $\cdots$ & -- & $\cdots$ & 3300 \\
\hline 1961 & -- & -- & --- & - & 3000 \\
\hline 1962 & -- & $\cdots$ & -- & 8200 & 2900 \\
\hline 1963 & $\cdots$ & $\cdots$ & $\cdots$ & 7300 & 2500 \\
\hline 1964 & 800 & 1100 & -.. & 6900 & 2600 \\
\hline 1965 & $\cdots$ & -- &.-- & 6600 & 2600 \\
\hline 1966 & --. & -. & -- & 6100 & 3000 \\
\hline 1967 & -. & --. & -- & 5500 & 3100 \\
\hline 1968 & -.- &.- & $\cdots$ & 5100 & 2800 \\
\hline 1969 & $\cdots$ & --- & -.- & 5300 & 3400 \\
\hline 1970 & --- & -- & -- & 4700 & 3600 \\
\hline 1971 & $\cdots$ & ... &.- & 4300 & 5000 \\
\hline 1972 & $\cdots$ & -- & -- & 3700 & 5500 \\
\hline 1973 & -- & -.. & - & 3700 & 5800 \\
\hline 1974 & 400 & 700 &.- & 4100 & 3200 \\
\hline 1975 & -- & -- & $\cdots$ & 3400 & 2700 \\
\hline 1976 & --. & --. & $\ldots$ & 3100 & 3700 \\
\hline 1977 & --- & -.- & -.. & 1600 & 3900 \\
\hline 1978 & 100 & 500 & $\cdots$ & 1600 & 2200 \\
\hline 1979 & -- & $\cdots$ & -.- & 1800 & 3600 \\
\hline 1980 & 300 & 1100 & -.- & 900 & 3800 \\
\hline 1981 & -- & $\cdots$ & --- & -. & 2900 \\
\hline 1982 & 200 & 400 & --- & -. & 3100 \\
\hline 1983 & -- & $\cdots$ & -- & -- & 1500 \\
\hline 1984 & $\cdots$ & $\cdots$ & -- & -- & 2400 \\
\hline 1985 & $\cdots$ & $\cdots$ & -- & -+ & 3000 \\
\hline 1986 & -.- &.- & -- & -- & 2800 \\
\hline 1987 & 85 & 300 & $\cdots$ & $\cdots$ & 2800 \\
\hline 1988 & $\ldots$ & -- & -- & --- & 3700 \\
\hline 1989 & --- & $\cdots$ & --- & --- & 4000 \\
\hline
\end{tabular}

${ }^{2}$ U.S. Dept. of Commerce U.S. Census of Agriculture, 1929-1987.

'U.S. Dept. of Agriculture Agricultural Marketing Service, 1961-1980.

'U.S. Dept. of Agriculture Agricultural Statistics, 1951-1990.

"---, Data unavailable. 


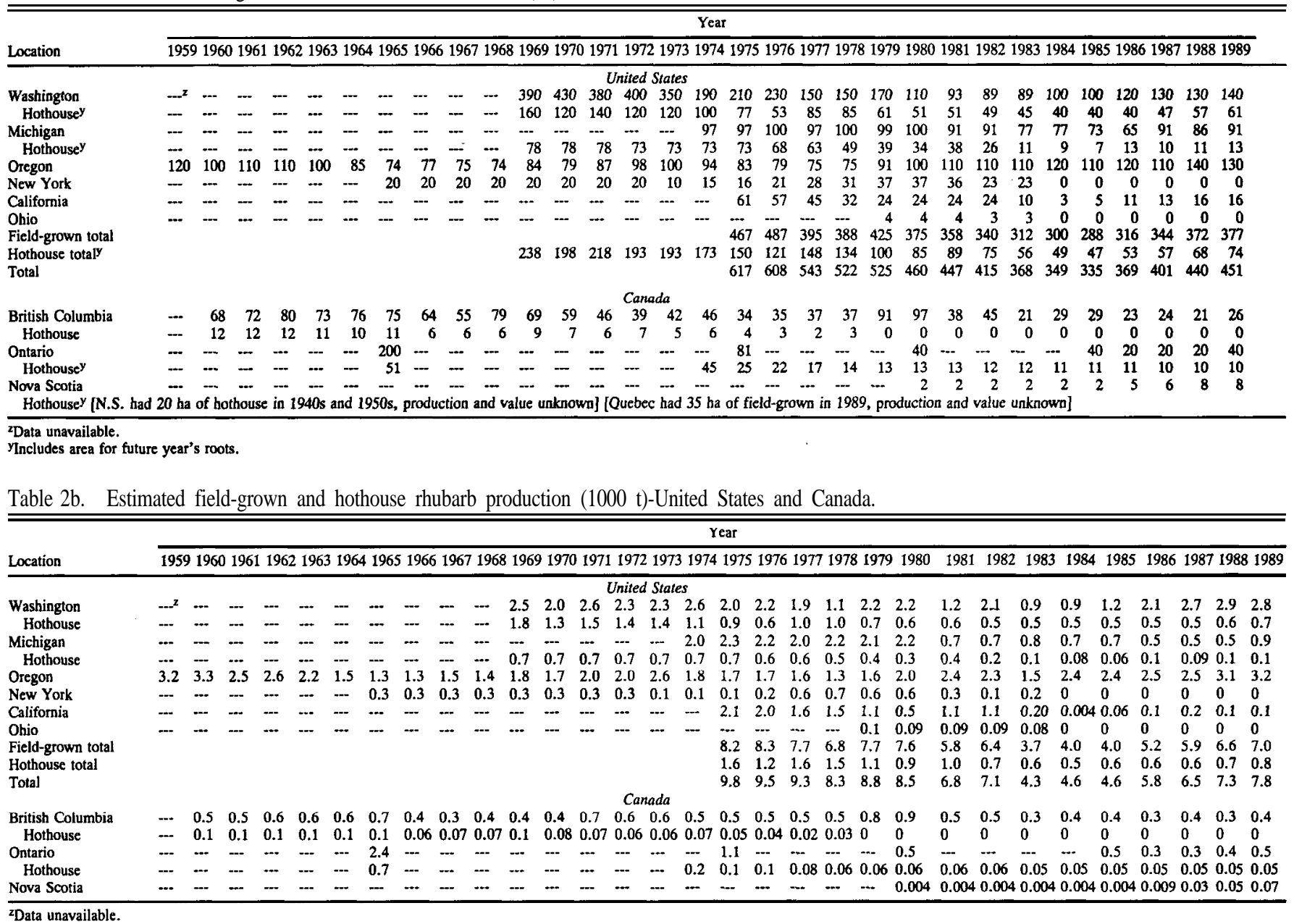

Data unavailable.

Table 2c. Estimated field-grown and hothouse rhubarb grower value (\$1000 United States and \$1000 Canadian)-United States and Canada.

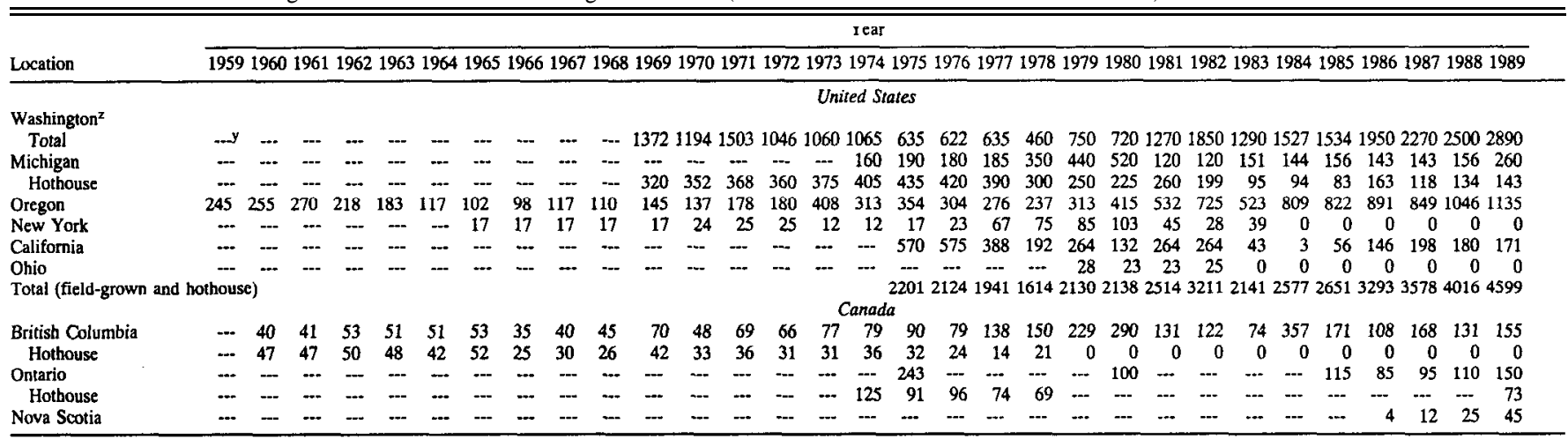

2Hothouse grower value not available separate from field-grown grower value.

y..., Data unavailable.

\section{DECLINE OF THE CULINARY RHUBARB INDUSTRY}

World War II appears to have marked the beginning of a decline in the culinary rhubarb industry. Wartime shortages, especially in fuels, skilled labor, sugar, and transport, placed a heavy burden on the small and specialized industry.

After the war, rhubarb production recovered perhaps too well. Supply exceeded demand in many areas, and market prices dropped disastrously. After a difficult period in which many growers were squeezed out of production and turned to other crops, the survivors recovered by the 1950s and 1960s, and rhubarb again became a valuable side activity, particularly for hothouse producers for whom the winter activity filled in otherwise unproductive months when field crops could not be tended. Postwar production, however, never achieved prewar levels; the number of farmers and the area planted were perhaps three-fifths of what they had been previously (Table 1). Yet, in the late 1950s, Michigan and Washington, the leading hothouse states, still had, respectively, -260 growers (perhaps 450 forcing sheds and 450 -
500 field hectares raising roots) and 120 growers (-300 sheds and 3000 ha). It has been estimated that Macomb County, Mich., alone produced 2500 to 3000 tons annually in the 1950s and 1960s with a value of $\$ 500,000$ to $\$ 750,000$. The largest jobber then handled, at rhubarb's peak in the area, some 55,000 to 60,000 cases (1300 to 1500 tons) annually, supplied by some 225 to 300 growers.

The mid-1960s, however, proved disappointing once again (Table $2 \mathrm{a}, \mathrm{b}$, and $\mathrm{c}$ ). Although in the late 1960 s, total U.S. production was still $\sim 8,000$ to $10,000 \mathrm{t}$, the 
markets for rhubarb reportedly weakened, or rather the supply exceeded the consumer demand at a price low enough for a specialty food item. The lack of consumer demand resulted in a long decline in the rhubarb industry that persists to this day, as exemplified particularly in the area and production tonnage of Oregon field-grown rhubarb (Table $2 \mathrm{a}$ and $\mathrm{b}$ ).

The reasons for the long-term slide in the industry are not yet a matter of common agreement. Consumer tastes are notoriously fickle and often beyond rational explanation. For whatever reason, it seems that rhubarb had lost some of its traditional appeal as an early spring cathartic. Certainly, also, the 1960s saw the popularization of new and varied foodstuffs and diets, often of exotic foreign origin. Most urbanites forgot about rhubarb or never learned of it.

Then, too, the oil shortages of 1973 and thereafter, which caused a sharp rise in fuel prices, shocked the forced-rhubarb farmers. The second half of the 1970s witnessed a precipitous decline in hothouse rhubarb as farmers abandoned their houses, not only because of the high fuel costs but also because of rising labor costs in an era of relatively high inflation. Table $2 \mathrm{a}$ and $\mathrm{b}$ illustrates this phenomenon, particularly in the states of Washington and Michigan, as well as in British Columbia. (Although statistics are not available to us, we know from anecdotal evidence that the Ontario hothouse industry also was ravaged by these factors.)

As these data reveal, hothouse and field rhubarb production continued to decline in the late 1970s and 1980s. There were efforts to reverse the trends. Considerable horticultural research (especially at the Stockbridge House Experimental Horticulture Station of North Yorkshire, but also at the Kentville, Nova Scotia, Experiment Station; the Vineland Horticultural Experiment Station in Ontario; and the Michigan State Univ.'s Horticultural Research Station) was devoted to improved cultivars that were disease resistant, prolific, hardy, and appealing in appearance. To address the problem of heavy labor costs, a mechanical harvester was developed and manufactured in 1976 (Marshall, 1986).

These efforts notwithstanding, the nadir was reached in 1983 and 1984 in both the United States and Canada, and the immediate cause seems to have been the rise in production in the late 1970s, which oversupplied declining urban markets. In the United States, for example, total production hovered between 8000 and 9000 t, only to be halved in the mid-1980s. British Columbia and Nova Scotia, on the western and eastern extremities of Canada, suffered a similar fate, if not quite as drastic (although the hothouse industry in the former province had already declined from nearly $140 \mathrm{t}$ two decades earlier to nil by 1979, as had that in the latter).
Hothouse rhubarb production was reduced to only three regions in North America. In 1989, total production was $<800 \mathrm{t}(80 \%$ from Washington, slightly $<15 \%$ from Michigan, and slightly $>5 \%$ from Ontario). Hothouse rhubarb represented overall only about a tenth of the total rhubarb production.

\section{NEW DEVELOPMENTS OFFER HOPE}

From the depressed years of the mideighties, a modest recovery has occurred in the past 6 or 7 years. The most dramatic improvement is the field-grown rhubarb of southern California. Employing mainly 'Cherry Giant', ranchers of the Los Angeles and San Diego areas are now in the midst of a revival. The key to their success is in the extraordinary productivity of this cultivar in a climate entirely unsuited to virtually all other cultivars, which require a distinct period of dormancy in the autumn and winter seasons. After 3 months of an entirely different kind of "dormancy" (June-August, during which the plants go dormant because of restricted irrigation and the leaves die back), substantial irrigation begins in late September or early October with the first harvest by November. As the year progresses, two or three additional harvests are possible, the only risk being that stalks may be pulled from young plants before the plants acquire sufficient root strength for long life. California ranchers sell most of their crop fresh and it is aggressively marketed throughout the West Coast and even east of the Rocky Mountains.

The recovery of recent years has been even greater in Washington, Oregon, and Michigan, as well as British Columbia and Nova Scotia (Table 2b). Total U.S. production in 1989, for example, was nearly double that of 1983 , conceding that the latter was a poor year, especially in California. Although figures for Ontario are incomplete, British Columbia and Nova Scotia both report improved markets, particularly for processing, and profitability at current price levels. The decline of the past two decades seems, for the moment, to have been arrested.

Some of the factors leading to this recovery appear to be the reverse of those that accounted for the decline in the 1960s. The poor years of the 1970s and 1980s drove many producers out of the business, leaving the industry to those with greater resources. It is tempting to conclude that the industry, having been purged of marginal growers, now is represented by the most skilled people with the greatest business acumen, but we have no hard evidence. Indeed, some of the successful current growers are new to the crop (in contrast to the past, when the secrets of cultivars and cultivation tended to be closely guarded), although virtually all have had considerable experience in other market crops. Marketing has improved noticeably, partly because of energetic growers' associations, particularly in Washington, Oregon, and Ontario, and partly because of attractive consumer packaging of instant-quick-frozen rhubarb intended for pies and tarts. In recent years, there have been several rhubarb festivals organized to promote culinary rhubarb, issue recipe books, and organize all sorts of competitions and activities centered on rhubarb. Finally, the taste for rhubarb, which appeared a decade or so ago to have been maintained only by the older generations and those with European heritages (according to one broker and processor) seems now to be spreading to other groups.

On the basis of this renewed popularity in recent years, it is possible to contemplate, at least, a return of the "Great Rhubarb Mania" of the 19th Century and the early decades of the 20th. Now the prerequisites for such popularity are more available than they were 100 years ago. The cultivars are varied and numerous, disease control is very advanced, fertility and cultural requirements are well developed, forcing technology is precisely understood, processing and marketing techniques are well known, and consumer uses plentiful.

\section{Literature Cited}

Akeroyd, J.R. 1989. Rheum Linnaeus, p. 124. In: S.M. Walter et al. (eds.). The European garden flora 3 (Pt. 1). Cambridge Univ. Press, Cambridge.

The Lancet. 1917. Poisoning by rhubarb leaves. The Lancet (London) 192:847.

Liberty Hyde Bailey Hortorium. 1976. Hortus third: A concise dictionary of plants cultivated in the United States and Canada. Macmillan, New York.

Livett, H.W. 1850. Rhubarb wine. Cottage Gardener 97:293-294.

Marshall, D.E. 1986. Design and performance of a mechanical harvester for field-grown rhubarb. Trans. Amer. Soc. of Agr. Eng. 29:6.52-656.

Marshall, D.E. 1988. A bibliography of rhubarb and Rheum species. Bibliographies and Literature of Agriculture, 62. U.S. Dept. Agr., Natl. Agr. Library, Agr. Res. Serv., Washington, D.C.

Mintz, S.W. 1985. Sweetness and power, the place of sugar in modem history. Viking, New York.

Tallqvist, H. and I. Vaananen. 1960. Death of a child from oxalic acid poisoning due to eating rhubarb leaves. Annales Paediatriae Fenniae 6:144-147.

Thorne, S. 1986. The history of food preservation. Parthenon Publishing, Kirkby Lonsdale, Cumbria, U.K.

U.S. Department of Commerce. 1929-1987. Specified vegetables for sale-farms and acres, U.S. census of agriculture. vol. 2. U.S. Dept. Commerce, Washington, D.C.

U.S. Department of Agriculture. Fresh fruit and vegetable unload totals for 41 cities, 1961-1980. Agr. Mktg. Serv. U.S. Dept. Agr. Washington, D.C.

U.S. Department of Agriculture. Vegetables, frozen: commercial. Agricultural statistics, 19511990. U.S. Dept. Agr. Washington, D.C. 